(c) 2018 - ISSN 1807-2577

\title{
Bond strength assessment of a universal adhesive system in etch-and-rinse and self-etch modes
}

\author{
Avaliação da resistência de união de um sistema adesivo universal no modo \\ convencional e autocondicionante
}

\author{
Gustavo do Prado SCHOENHALS ${ }^{a}$ (D) , Cinthia Lais BERFT $^{\mathrm{a}}(\mathbb{D})$, Fabiana Scarparo NAUFEL $^{\mathrm{b}}$ (D), \\ Vera Lucia SCHMITT' ${ }^{\text {b }}$, Larissa Pinceli CHAVES ${ }^{a^{*}}$ (1) \\ aUNIPAR - Univesidade Paranaense, Campus Cascavel, Cascavel, PR, Brasil \\ bUNIOESTE - Universidade Estadual do Oeste do Paraná, Campus Cascavel, Cascavel, PR, Brasil
}

How to cite: Schoenhals GP, Berft CL, Naufel FS, Schmitt VL, Chaves LP. Bond strength assessment of a universal adhesive system in etch-and-rinse and self-etch modes. Rev Odontol UNESP. 2019;48:e20190083. https://doi.org/10.1590/18072577.08319

\begin{abstract}
Resumo
Introdução: A odontologia moderna é refletida na inserção de novos materiais com diferentes formas de adesão nas estruturas dentárias, como o sistema adesivo Universal. Objetivo: Avaliar a resistência adesiva do sistema adesivo universal em dentina, na forma de aplicação auto condicionante e convencional, comparando com um sistema adesivo convencional simplificado, em dois períodos distintos: 1 semana e 6 meses. Material e método: Foram selecionados 48 incisivos bovinos separados em 6 grupos, armazenados por 7 dias. Desgastado o esmalte vestibular, até exposição da dentina. Aplicaram-se os adesivos Adper Single Bond 2 (3M Espe) ou SingleBond Universal (3M Espe), e sobre este, posicionados cateteres preenchidos com o compósito Opallis Flow (FGM). Após fotoativação, removeram-se os cateteres e expuseram-se os corpos de prova $(\mathrm{n}=48)$, armazenados em água destilada a $37{ }^{\circ} \mathrm{C}$ por uma semana e seis meses. Os corpos de prova foram fixados uma máquina universal de ensaios (EMIC DL 2000), com velocidade de 0,5 mm/min. A resistência de união (RU) foi calculada em $\mathrm{MPa}$, e os dados foram analisados estatisticamente pela Anova e pelo teste de Tukey ao nível de 5\% de significância. Resultado: Para Adper Single bond, a RU foi equivalente nos tempos testados; para Universal modo convencional e autocondicionante o tempo influenciou na RU, havendo um decréscimo nos resultados. Em 1 semana, todos os adesivos foram diferentes entre si, com maior RU para Universal modo convencional, seguido por universal modo autocondicionante e então pelo Adper Single bond. Conclusão: 0 melhor desempenho foi do adesivo universal na forma convencional nos dois tempos testados.
\end{abstract}

Descritores: Sistema adesivo universal; resistência adesiva; microcisalhamento; self-etch; total-etch; 10-MDP.

\begin{abstract}
Introduction: Modern dentistry is reflected in the insertion of new materials with different adhesion forms in dental structures, such as the Universal adhesive system. Objective: To evaluate the bond strength of the universal dentin adhesive system, in the form of self-etching and conventional application, compared with a simplified conventional adhesive system, in two distinct periods: 1 week and 6 months. Material and method: 48 bovine incisors separated into 6 groups, stored for 7 days, were selected. Worn out the buccal enamel until dentin exposure. Adper Single Bond 2 (3M Espe) or SingleBond Universal (3M Espe) adhesives were applied, and catheters filled with Opallis Flow (FGM) composite were placed. After photoactivation, the catheters were removed and the specimens $(n=48)$, stored in distilled water at $37{ }^{\circ} \mathrm{C}$ for one week and six months, were exposed. The specimens were fixed to a universal testing machine (EMIC DL 2000) with a speed of $0.5 \mathrm{~mm} / \mathrm{min}$. Bond strength (BS) was calculated in MPa, and data were statistically analyzed by Anova and Tukey test at $5 \%$ significance level. Result: For Adper Single
\end{abstract}


bond, the BS was equivalent in the times tested; for Universal conventional and self-conditioning time influenced the BS, with a decrease in the results. At 1 week, all stickers were different from each other, with higher BS for Universal conventional mode, followed by universal self-etching mode and then Adper Single bond. Conclusion: The best results were achieved with universal adhesive in conventional mode for both tested times.

Descriptors: Universal adhesive system; bond strength; microshear; self-etch; etch-and-rinse; 10-MDP.

\section{INTRODUCTION}

Modern dentistry is reflected by the introduction of new materials with different bonding to dental structures in order to return the biological, mechanical, and aesthetic functions of teeth. Considering the great number of adhesive systems in the market and the various application protocols, dentists often do not apply the material correctly, resulting in failure of the procedures performed.

Currently, adhesive systems may be classified as etch-and-rinse and self-etching. Etch-and-rinse adhesives depend on the prior demineralization of enamel and dentin with an acid. They are classified in three clinical steps, in which primer and adhesive are applied separately, or in two steps, in which primer and adhesive are included in one single bottle ${ }^{1}$. However, several studies show a series of problems for etch-and-rinse adhesives, such as postoperative sensitivity, marginal staining, and adhesive failures after some time of use ${ }^{2}$.

Self-etching systems, in turn, have acid primer and adhesive. They may be classified in two steps, in which the adhesive is applied separately from the acid primer, or in one single step, in which the three components are applied at the same time, allowing demineralization and simultaneous infiltration in the dentin tissue. However, the results in enamel are unfavorable, requiring prior enamel acid etching ${ }^{3}$ with the risk of dentin contamination. In order to reduce the amount of materials, universal adhesives appeared with various applications.

The advantage of this modern adhesive system is the ease of working time, considering that one single bottle presents the acid primer and the adhesive itself, allowing faster and easier application than other adhesive systems in the market. This new proposal offers dentists the choice of using the best technique, which may be etch-and-rinse, selective etching in enamel, or self-etching. The techniques may also be used with silane or primer for metal and ceramics, simplifying the clinical practice ${ }^{4}$.

This study aims to assess the bond strength of a universal adhesive system in dentin, in etch-and-rinse and self-etch application modes, comparing it with a simplified conventional adhesive system at two different times: one week and six months of storage in distilled water.

\section{MATERIAL AND METHOD}

\section{Obtaining the Teeth}

The 48 bovine incisors selected were extracted and their crowns were cut from the root aided by a double-sided flexible diamond disc (ref. 7016. KG Sorensen Barueri, SP, Brazil) under refrigeration. After sectioning, the teeth were separated randomly into six groups, which were stored in $0.9 \%$ saline solution in a freezer $\left(-18^{\circ} \mathrm{C}\right)$ for seven days. 


\section{Removing the Buccal Enamel}

After seven days of storage, each group was prepared for the production of specimens. The enamel of the buccal surface was worn until dentin exposure with \#600-grit silicon carbide papers assembled in a horizontal cutting machine (Polisher, model AP1-4 Arotec, Cotia, SP, Brazil) under refrigeration, to create a standardized and newly formed dentin smear.

\section{Including Teeth in the Acrylic Resin}

In a PVC tube filled with acrylic resin, each tooth was positioned on a portion of Durepoxi (Henkel Ltda., Itapevi, SP, Brazil) manipulated at the ratio of 1:1. Next, the teeth were fixed with the worn surface parallel to the ground, using a parallelometer.

The materials used are described in Table 1.

\section{Preparing the Specimens}

Table 1 - Composition of the materials used

\begin{tabular}{|c|c|c|c|}
\hline Product & Batch & Chemical composition & Manufacturer \\
\hline $\begin{array}{l}\text { Single Bond Universal } \\
\text { pH } 2.7\end{array}$ & 645026 & $\begin{array}{c}\text { Vitrebond copolymer, } \\
\text { HEMA, MDP, } \\
\text { dimethacrylate resins, } \\
\text { silane, water, ethanol, } \\
\text { primers }\end{array}$ & $\begin{array}{c}\text { 3M, Deutschland, } \\
\text { Universal Germany - 3M do } \\
\text { Brasil Ltda. }\end{array}$ \\
\hline $\begin{array}{l}\text { Adper Single Bond } 2 \\
\text { pH } 4.7\end{array}$ & N808310 & $\begin{array}{c}\text { Vitrebond copolymer, } \\
\text { HEMA, water, ethanol, } \\
\text { primers }\end{array}$ & $\begin{array}{c}\text { 3M ESPE, Irvine, California, } \\
\text { USA }\end{array}$ \\
\hline $37 \%$ phosphoric acid & 061017 & $\begin{array}{l}\text { 37\% phosphoric thickener, } \\
\text { dye, and deionized water }\end{array}$ & $\begin{array}{c}\text { Dentscare LDTA, FGM, } \\
\text { Joinville, SC, BR }\end{array}$ \\
\hline Opallis Flow color A2 & $\begin{array}{l}060617 \\
090817\end{array}$ & $\begin{array}{c}\text { 72\% inorganic load, } \\
\text { methyl esters, monomers } \\
\text { (TEGDMA, Bis GMA, and } \\
\text { EMA), camphorquinone, } \\
\text { co-primers, preservatives, } \\
\text { and pigments }\end{array}$ & $\begin{array}{c}\text { Dentscare LDTA, FGM, } \\
\text { Joinville, SC, BR }\end{array}$ \\
\hline
\end{tabular}

Cylinders were fabricated (three or four per sample) with Opallis photopolymerizable composite resin (FGM, Joinville, SC, Brazil), of color A2 and approximately $6 \mathrm{~mm}$ of height, using a catheter segment of $1.4 \mathrm{~mm}$ of internal diameter (Vitromed Healthcare, Jaipur, Rajasthan, India).

These catheters were placed over the teeth in areas defined with perforated adhesive tape. The applicator tip of the flow resin filled the catheter in approximately $6 \mathrm{~mm}$ of height, followed by light-curing (Valo photopolymerizer, Ultradent, South Jordan, UT, USA) for 40 seconds, under wavelength of $395-480 \mathrm{~nm}$ and power of $3200 \mathrm{~mW} / \mathrm{cm}^{2}$. After photopolymerization, the delimiting tape and the catheter were removed.

The tooth/composite resin cylinder sets were stored in distilled water for their times (one week or six months - Table 2 ) in a $37^{\circ} \mathrm{C}$ oven. 
Table 2. Distribution of experimental groups and application modes of the adhesive system

\begin{tabular}{|c|c|c|}
\hline \multicolumn{3}{|c|}{ Application of adhesive systems } \\
\hline Time & Group & Application \\
\hline $\begin{array}{l}\text { One week } \\
\text { Six months }\end{array}$ & $\begin{array}{c}\text { Single Bond Universal Etch-and- } \\
\underline{\text { rinse }} \\
\underline{\text { SB UC) }}\end{array}$ & $\begin{array}{c}1^{\text {st }} 37 \% \text { phosphoric acid for } 15 \text { seconds; } \\
2^{\text {nd }} \text { Washing with water spray for } 15 \text { seconds; } \\
3^{\text {rd }} \text { Excess removal with absorbent paper; } \\
4^{\text {th }} \text { Adhesive with microbrush rubbed for } 20 \text { seconds; } \\
5^{\text {th }} \text { Mild air blast for } 5 \text { seconds; } \\
6^{\text {th }} \text { Light-curing for } 10 \text { seconds. }\end{array}$ \\
\hline $\begin{array}{l}\text { One week } \\
\text { Six months }\end{array}$ & $\begin{array}{l}\frac{\text { Single Bond Universal }}{\text { Self-etching }} \\
\text { (SB UA) }\end{array}$ & $\begin{array}{l}1^{\text {st }} \text { Adhesive with microbrush rubbed for } 20 \text { seconds; } \\
2^{\text {nd }} \text { Mild air blast for } 5 \text { seconds; } \\
3^{\text {rd }} \text { Light-curing for } 10 \text { seconds. }\end{array}$ \\
\hline $\begin{array}{l}\text { One week } \\
\text { Six months }\end{array}$ & $\frac{\text { Adper Single Bond }}{\frac{\text { Conventional }}{(\mathrm{SB} \mathrm{C})}}$ & $\begin{array}{c}1^{\text {st }} 37 \% \text { phosphoric acid for } 15 \text { seconds; } \\
2^{\text {nd }} \text { Washing with water spray for } 15 \text { seconds; } \\
3^{\text {rd }} \text { Water excess removal with absorbent paper; } \\
4^{\text {th }} \text { Adhesive in dentin with microbrush for } 15 \text { seconds and } \\
\text { a second round of adhesive rubbed for } 10 \text { seconds; } \\
5^{\text {th }} \text { Mild air blast for } 5 \text { seconds; } \\
6^{\text {th }} \text { Light-curing for } 10 \text { seconds. }\end{array}$ \\
\hline
\end{tabular}

\section{Microshear Test}

The samples were attached to a universal testing machine EMIC DL-200 MF (São José dos Pinhais, PR, Brazil). The microshear load was applied to the base of the cylinders with a steel wire $(0.2 \mathrm{~mm}$ of diameter $)$ at speed of $0.5 \mathrm{~mm} / \mathrm{min}$ until breaking the bond, using a load cell of $50 \mathrm{~N}$.

The microshear bond strength of each cylinder was calculated and expressed (MPa) through the MTest 2000 software by a computer connected to a testing machine, and the mean of three specimens was taken for each sample. The results were analyzed statistically with Analysis of Variance (ANOVA) and Tukey's test at 5\% significance.

\section{RESULT}

The double interaction showed significant differences $(\mathrm{p}=0.001)$. In one week, all adhesives were different among each other, showing the highest bond strength (BS) for the universal adhesive in etch-and-rinse mode (SB UC), followed by the self-etch mode and the Adper Single Bond. In six months, the etch-and-rinse universal adhesive was superior, differing from the self-etch mode, which showed the lowest BS at this time. Adper Single Bond showed intermediate BS and it did not differ from the others. For Adper Single Bond, BS was equivalent in six months, while for etch-and-rinse and self-etch universal adhesives, BS was lower after six months (Table 3 and Figure 1).

Table 3. Results presented

\begin{tabular}{cccc}
\hline & AS C & SB UC & SB UA \\
\hline One week & $15.07 \pm 3.72 \mathrm{Ac}$ & $31.47 \pm 7.83 \mathrm{Aa}$ & $22.44 \pm 5.51 \mathrm{Ab}$ \\
Six months & $19.19 \pm 4.83 \mathrm{Aab}$ & $21.51 \pm 6.45 \mathrm{Ba}$ & $13.79 \pm 4.18 \mathrm{Bb}$ \\
\hline
\end{tabular}

$\mathrm{N}=8, \mathrm{p}<0.05$. Capital letters indicate statistically significant differences between the times. Lower-case letters indicate statistically significant differences between the treatments at the same time. 


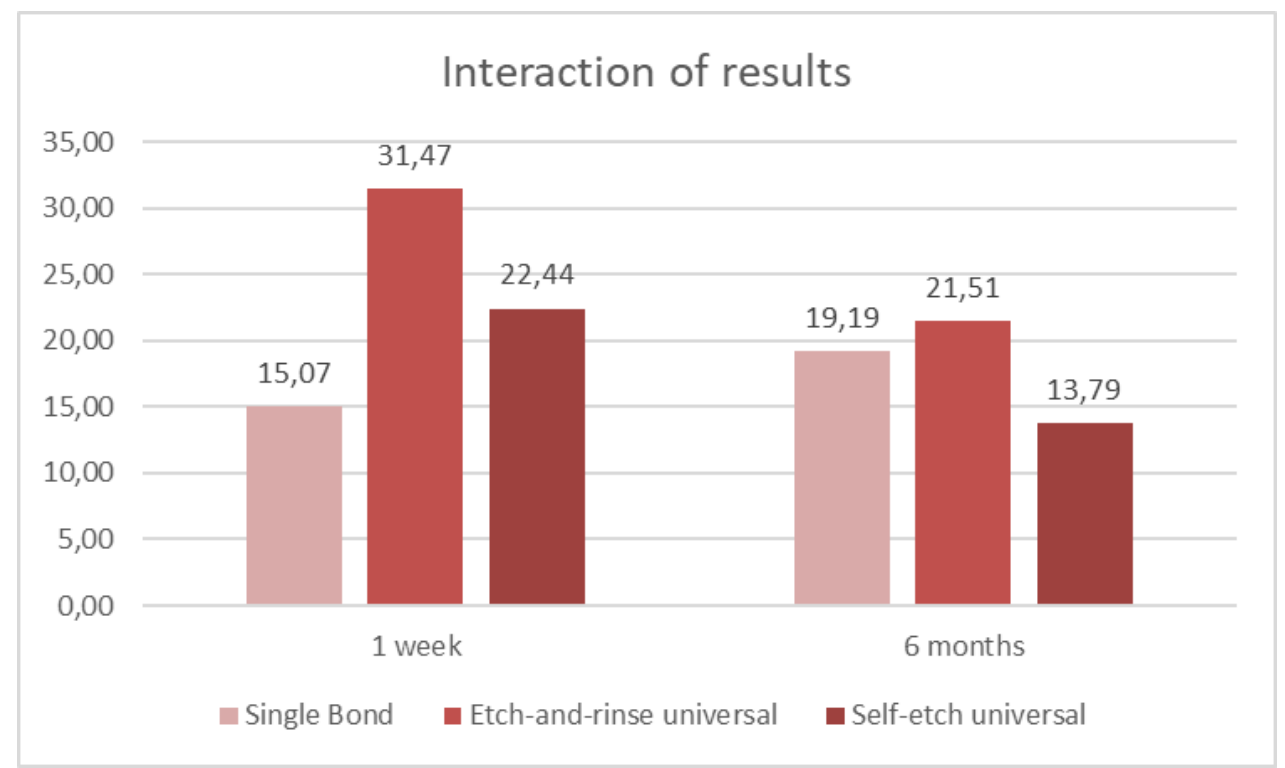

Figure 1. Interaction of results at one week and six months using the Single Bond Universal and conventional Adper Single Bond adhesives.

\section{DISCUSSION}

The frequent development of new adhesive systems requires studies to assess the bond strength of these materials in the dental substrate, in both immediate and long-term analyses, assessing the durability of such bond. The present study selected the microshear test due to the potential to produce several specimens in one sample ${ }^{5}$. It differs from the microtensile test, which requires cutting the samples, demands more time, and presents more performance challenges and problems in propagating forces in the bonding interface ${ }^{6}$.

The null hypothesis tested in the present study was rejected, because there was statistical difference in bond strength between the adhesive systems. In one week, the universal adhesive system in the etch-and-rinse mode (SB UC) showed the highest bond strength followed by the self-etch mode (SB AU), while the conventional Adper Single Bond 2 adhesive system (AS C) showed the lowest bond strength. The six-month assessment showed statistical difference between the groups of the universal adhesive system, with reduction of values when compared to the time of one week. The Adper Single Bond adhesive, in turn, did not present statistical difference between the times tested. In six months, the SB UC maintained the highest bond strength followed by AS C, while the SB AU presented the lowest bond strength.

The priority of this study was to assess the bond strength in dentin, because enamel already shows a consensus on the prior use of $35-37 \%$ phosphoric acid for 30 seconds ${ }^{7,8}$. In enamel acid-etching, the mineral content is removed, opening inter- and intraprismatic spaces and producing a more reactive surface due to the microporosities absorbed by the capillarity of the resin monomers of adhesive, thus forming the hybrid layer ${ }^{9,10}$. Therefore, these studies showed higher bond strength in prior enamel acid-etching.

The application in dentin, in turn, is extensively studied, because it presents regional variations of dentinal tubules, humidity, and depth, as well as pathological and physiological changes to which this substrate is subjected, making the dentinal bond complex and difficult to control $^{11}$. Therefore, we chose to assess the dentinal substrate, because the universal adhesive system allows several application forms.

Acid-etching in dentin for 15 seconds promotes the complete removal of smear layer and smear plugs, opening the dentinal tubules and demineralizing intertubular and peritubular dentin, which results in a demineralized layer that may vary around $5 \mu \mathrm{m}^{12}$. The difference of 
thickness of the hybrid layer may be one of the hypotheses for the etch-and-rinse bond strength results to be superior to the self-etch mode.

The composition of the universal adhesive system, also called multi-mode adhesive system, presents the 10-methacryloyloxydecyl dihydrogen phosphate acid monomer (10-MDP) and a polyalkenoic acid copolymer, which can form MDP-Ca salts with hydroxyapatite, promoting chemical bond and stability in aqueous medium. These compounds are also responsible for maintaining the $\mathrm{pH}$ of the product close to 2 . Thus, part of the dentin is demineralized and penetrates the resin monomers simultaneously, forming a hybrid layer of $1 \mu \mathrm{m}$ in average. This stability in aqueous medium is explained by the formation of a long carbon chain that provides hydrophobic properties and hydrolytic stability ${ }^{13}$. This composition is the differential of universal adhesive systems when comparing etch-and-rinse and self-etch modes.

Another monomer included in the composition of Scotch Bond Universal is the Vitrebond copolymer, which is a hydrophobic monomer produced by the manufacturer (3M ESPE), and it is responsible for rehydrating the collagen fibers that remain stable in aqueous medium, infiltrating the adhesive system throughout the entire demineralized depth in prior acid etching. Therefore, it may improve the strength results in the etch-and-rinse application mode, considering the depth of the hybrid layer is close to $5 \mu \mathrm{m}$, as aforementioned.

Studies comparing the application form of simplified and complex adhesive systems conclude that adhesives with reduced number of steps present a decrease in bond strength values after some storage time, when compared to adhesive systems with several application steps. This emphasizes that simplifications produce less favorable results in the long-term and that infiltration depth is lower in the self-etch mode, forming a thinner hybrid layer and consequently smaller resin tags ${ }^{14-17}$.

The comparison of the study by Walter et al. ${ }^{18}$ with the present study shows that although the universal adhesive is all-in-one and presents several functions, it obtained higher immediate dentin bond results than a simplified conventional adhesive (single bottle). This may be due to the different composition of each adhesive system, considering the universal adhesive is composed by different monomers such as 10 -MDP. However, over time, the bond results of universal adhesives decrease, but are higher than conventional adhesives.

Studies assessing the bond strength of universal adhesives concludes they have higher bond strength than other types of adhesive systems, showing the differential components of 10-MDP and polyalkenoic acid as a hypothesis for improved results. These components form chemical bonds with calcium and MDP-Ca salts and the micromechanical bond that has been studied and proved for other adhesive systems, as well as silane, which forms a bond with the inorganic substrate of resin for being a bifunctional molecule ${ }^{13-19}$. This concludes that such components are the differential of the universal adhesive system.

However, the universal adhesive system requires longitudinal studies that assess its strength and performance in the long-term, because, as verified in this study, the bond strength values are higher than the other adhesive systems, but they decrease over time.

\section{CONCLUSION}

This study proves that the universal adhesive system (Single Bond Universal - 3M ESPE) presents the highest bond strength in the etch-and-rinse application mode when compared to the self-etching application in dentin tissue. Moreover, it shows that, regardless of prior acid etching or not, the universal adhesive system resulted in higher bond strength than the two-step conventional adhesive system (Adper Single Bond - 3M ESPE). 


\section{REFERENCES}

1. De Munck J, Van Landuyt K, Peumans M, Poitevin A, Lambrechts P, Braem M, et al. A critical review of the durability of adhesion to tooth tissue: methods and results. J Dent Res. 2005 Feb;84(2):118-32. http://dx.doi.org/10.1177/154405910508400204. PMid:15668328.

2. Muñoz MA, Luque I, Hass V, Reis A, Loguercio AD, Bombarda NH. Immediate bonding properties of universal adhesives to dentine. J Dent. 2013 May;41(5):404-11. http://dx.doi.org/10.1016/j.jdent.2013.03.001. PMid:23499568.

3. Rosa WL, Piva E, Silva AF. Bond strength of universal adhesives: a systematic review and metaanalysis. J Dent. 2015 Jul;43(7):765-76. http://dx.doi.org/10.1016/j.jdent.2015.04.003. PMid:25882585.

4. Hanabusa M, Mine A, Kuboki T, Momoi Y, Van Ende A, Van Meerbeek BV, et al. Bonding effectiveness of a new 'multi-mode' adhesive to enamel and dentine. J Dent. 2012 Jun;40(6):475-84. http://dx.doi.org/10.1016/j.jdent.2012.02.012. PMid:22381614.

5. Shimada Y, Yamaguchi S, Tagami J. Micro-shear bond strength of dual-cured resin cement to glass ceramics. Dent Mater. 2002 Jul;18(5):380-8. http://dx.doi.org/10.1016/S0109-5641(01)00054-9. PMid:12175577.

6. Harnirattisai C, Roengrungreang P, Rangsisiripaiboon U, Senawongse P. Shear and micro-shear bond strengths of four self-etching adhesives measured immediately and 24 hours after application. Dent Mater J. 2012;31(5):779-87. http://dx.doi.org/10.4012/dmj.2012-013. PMid:23037841.

7. Di Hipólito V, Goes MF, Carrilho MR, Chan DC, Daronch M, Sinhoreti MA. SEM evaluation of contemporary self-etching primers applied to ground and unground enamel. J Adhes Dent. 2005;7(3):203-11. PMid:16240961.

8. Zhou L, Wang Y, Yang H, Guo J, Tay FR, Huang C. Effect of chemical interaction on the bonding strengths of self-etching adhesives to deproteinised dentine. J Dent. 2015 Aug;43(8):973-80. http://dx.doi.org/10.1016/j.jdent.2015.05.010. PMid:26054235.

9. Frankenberger R, Tay FR. Self-etch vs etch-and-rinse adhesives: effect of thermo-mechanical fatigue loading on marginal quality of bonded resin composite restorations. Dent Mater. 2005 May;21(5):397412. http://dx.doi.org/10.1016/j.dental.2004.07.005. PMid:15826696.

10. Poggio C, Scribante A, Della Zoppa F, Colombo M, Beltrami R, Chiesa M. Shear bond strength of one-step self-etch adhesives to enamel: effect of acid pretreatment. Dent Traumatol. 2014 Feb;30(1):43-8. http://dx.doi.org/10.1111/edt.12027. PMid:23297838.

11. Takamizawa T, Barkmeier WW, Tsujimoto A, Berry TP, Watanabe H, Erickson RL, et al. Influence of different etching modes on bond strength and fatigue strength to dentin using universal adhesive systems. Dent Mater. 2016 Feb;32(2):e9-21. http://dx.doi.org/10.1016/j.dental.2015.11.005. PMid:26719131.

12. Sarr M, Kane AW, Vreven J, Mine A, Van Landuyt KL, Peumans M, et al. Microtensile bond strength and interfacial characterization of 11 contemporary adhesives bonded to bur-cut dentin. Oper Dent. 2010 Jan-Feb;35(1):94-104. http://dx.doi.org/10.2341/09-076-L. PMid:20166416.

13. Anchieta RB, Machado LS, Martini AP, Santos PH, Giannini M, Janal M, et al. Effect of long-term storage on nanomechanical and morphological properties of dentin-adhesive interfaces. Dent Mater. 2015 Feb;31(2):141-53. http://dx.doi.org/10.1016/j.dental.2014.11.010. PMid:25529501.

14. Tjäderhane L. Dentin bonding: can we make it last? Oper Dent. 2015 Jan-Feb;40(1):4-18. http://dx.doi.org/10.2341/14-095-BL. PMid:25615637.

15. Pashley DH, Tay FR, Breschi L, Tjäderhane L, Carvalho RM, Carrilho M, et al. State of the art etch-andrinse adhesives. Dent Mater. 2011 Jan;27(1):1-16. http://dx.doi.org/10.1016/j.dental.2010.10.016. PMid:21112620. 
16. Van Meerbeek B, Yoshihara K, Yoshida Y, Mine A, DeMunck J, Van Landuyt KL. State of the art of selfetch adhesives. Dent Mater. 2011 Jan;27(1):17-28. http://dx.doi.org/10.1016/j.dental.2010.10.023. PMid:21109301.

17. Manfroi FB, Marcondes ML, Somacal DC, Borges GA, Júnior LH, Spohr AM. Bond strength of a novel one bottle multi-mode adhesive to human dentin after six months of storage. Open Dent J. 2016 Jun 6;10:268-77. http://dx.doi.org/10.2174/1874210601610010268.

18. Walter R, Swift EJ Jr, Nagaoka H, Chung Y, Bartholomew W, Braswell KW, et al. Two-year bond strengths of "all-in-one" adhesives to dentine. J Dent. 2012 Jul;40(7):549-55. http://dx.doi.org/10.1016/j.jdent.2012.03.003. PMid:22429926.

19. Jang JH, Lee MG, Woo SU, Lee CO, Yi JK, Kim DS. Comparative study of the dentin bond strength of a new universal adhesive. Dent Mater J. 2016;35(4):606-12. http://dx.doi.org/10.4012/dmj.2015-422. PMid:27477226.

\section{CONFLICTS OF INTERESTS}

The authors declare no conflicts of interest.

\section{${ }^{*}$ CORRESPONDING AUTHOR}

Larissa Pinceli Chaves, Rua João Pessoa 61, apto 200, Centro, 85812-070 Cascavel - PR, Brasil, e-mail: lpchaves@terra.com.br

Received: August 12, 2019

Accepted: September 18, 2019 